\title{
Puerto Ricans in the USA: a comparative approach.
}

\author{
by Ramon Grosfoguel
}

\section{@ COPYRIGHT1999 Commission for Racial Equality (UK)}

\begin{abstract}
This article discusses Puerto Rican migration within the broader context of Caribbean migration to the USA. The first part discusses the theoretical framework. The labour market incorporation of migrants is conceptualised as a result of the sociopolitical modes of incorporation which among other dimensions include the US foreign policy/geo-politics in the region; public opinion/perception of the migrants within the host society; the presence or absence of a migrant community as well as the class/racial composition of the migrants and the the sending country's core-periphery relationships. The historical origins of Caribbean migration to the USA are examined next, whereupon the article moves on to discuss the class origin of the post-1960s Caribbean migrants. Modes of incorporation to the host society are then explored, as is the foundational myth that forms part of US narratives about the nation and the way this affected the mode of incorporation for Puerto Ricans. Finally, the article discusses the challenges which the identification strategies adopted by Puerto Ricans pose to traditional conceptualisations of identity. In sum, this article portrays the multiple complex dimensions that determine the Puerto Rican migrants' particular mode of incorporation in the host society.
\end{abstract}

The traditional sociological paradigms on immigrants in the USA have been based on ethnicity approaches: the assimilation school (Gordon 1964; Park 1950) and the cultural pluralist school (Glazer and Moynihan 1963). Both schools used the turn of the century European migrations as a model. According to the assimilation school, all groups pass through several stages in the process of assimilation to the host society. First, they become acculturated to the values, norms and culture of the host society. Usually it takes two or three generations to lose their native language, values and culture of origin. Second, once assimilated to 'Anglo-American' culture, which eliminates any discriminatory obstacles that could affect their successful incorporation to the labour market, they are structurally assimilated to the mainstream American economy. The first generation normally makes the big economic sacrifices to further the fortunes of the next generations.

The cultural pluralist school assumes a similar teleological stagism but with one main difference. Even though ethnic groups eventually assimilate, this does not mean that the new identity is a 'melting' identity that belongs to a homogenous 'American' culture. Groups lose their language and customs but ethnicity continues to be recreated in a new form of identity that is neither a 'melting pot' nor a simple repetition of their communities of origin. It is a new hyphenated identity (i.e. Irish-American, Italian-American, Polish-American) that emerges out of common political interests. They are interest groups that deliver political power that is eventually translated into economic gains, leading to 'upward mobility' for the whole community.

The more sophisticated versions of both schools recognised that their models need to take into account processes of discrimination through extra-economic means such as the black experience in the USA (Glazer and Moynihan 1963; Gordon 1964). They recognised that despite the cultural 'assimilation' of black people, they experienced discriminatory obstacles that affected their integration to the mainstream of the American economy unlike European ethnic groups. However, the 'cultural pluralist' and the 'assimilation' schools shared two basic assumptions. First, the longer an ethnic group is in the USA, the more structurally assimilated or integrated they become to the mainstream American economy. Second, once equal opportunity legislation was enforced, black, Hispanic or Asian individuals experienced the same processes of integration as any other ethnic group in the USA. The timing of the migration as well as the racial discrimination suffered by immigrants of colour are erased from the analysis. The assumption is one of a unilinear process of integration into the host society. Moreover, the cultural pluralist school recognises the ethnicity of all the 'white' groups, but subsumes 'black', 'Hispanic' and 'Asian' groups under the 'they all look alike' racial reductionism (Omi and Winant 1986). The diverse ethnic groups among the black, Latino and Asian populations are not recognised within this paradigm. They keep using racialised categories to lump together a diversity of ethnic groups. In this article a variety of ethnic groups that are erased with the use of racialised categories such as Hispanic or black will be distinguished. This will allow for important analytical distinctions between different ethnic groups depending on class origin, educational backgrounds, the political economy of the city, and the broad context of incorporation to the new society.

Recent approaches to migration emphasised the context of reception to the host society and the modes of incorporation to the labour market (Portes and Borocz 1989; Portes and Rumbaut 1990). The context of reception refers to the state 


\section{Puerto Ricans in the USA: a comparative approach.}

policies toward a specific migrant group, the reaction/perceptions of the public opinion, and the presence or absence of an ethnic community. This context provides the sociological framework that determines the diverse labour market incorporation. This approach represents an improvement over the timeless and unilinear deterministic conceptualisations of the old paradigms. However, this approach conceptualises the context of reception and modes of incorporation in terms of the national setting of a nation state, overlooking the global historical-structural processes that overdetermine the context of reception. In the case of the Caribbean region, the positive, negative or neutral nature of US state policies toward a migrant group is frequently related to foreign policy and geo-political strategies. Two points need to be emphasised.

First, it is crucial to locate each migrant group within the broader context of the global relationships between their state of origin and the USA (Petras 1981). For example, whether the core-periphery relationship is colonial, neocolonial with an active military intervention on the part of the USA, or neocolonial without geo-political importance for the core state, makes a difference in terms of: 1) the migrants' class origin and educational backgrounds, 2) the USA's policies regarding their incorporation, and 3) the public perception of the migrants, which, in turn, affects the modes of incorporation into the labour market. The geographical proximity of a peripheral state to the core state allows lower class migrants to bypass the institutional barriers to migration by crossing the borders legally or illegally (i.e. Mexico). Caribbean migration, given the region's geographic formation as an archipelago of multiple islands, is more vulnerable to state and institutional policies. It is difficult to overcome the institutional barriers to migration when there is an ocean separating the sending and receiving countries. A somewhat different case is represented by countries that have broken the neo-colonial linkage with the USA and are treated by American foreign policy as enemies (e.g. Cuba, Nicaragua during the Sandinista regime, Vietnam). In these cases, the migrants were frequently treated as refugees within a more positive context of reception than applied to many other immigrants.

Second, an important, and frequently overlooked, aspect which is central to the context of reception is the racial/ethnic composition of the migrants. The difference between 'white' Europeans and those other than white is a crucial axis that articulates social relations in the USA. There are groups of migrants that are socially constructed as 'white' such as European migrants, others that are constructed as 'black' such as certain migrations from the English-speaking Caribbean, there are groups that despite a mixed racial composition are nevertheless racialised as a group. Puerto Ricans and Mexican-Americans are examples. All of these variations in racialisation and colonial experiences are crucial to understanding the different reception of an immigrant group in a racialised society such as the USA.

Thus, it is important to look at the totality of the migration process of each migrant group in its historical-structural complexity, that is, to analyse the time and space dimensions as well as the racial and ethnic dynamics, in order to understand why some groups are more successfully incorporated to the labour market than others: Where are they coming from and why? When did they arrive? What is the dominant class origin of the migration flow? What is the racial/ethnic composition? Where did they settle? What are the geo-political, economic and social dimensions of the migration processes for each immigrant group? What are the relations between the host society and the country of origin? What is the history and political economy of the region they settled in at the time they migrated? What is the context of reception for each different migrant group in the city in which they settled? How did the narratives of the nation in the host society affect the migrants' identity and/or racialisation processes? After accounting for all these factors, we can start making sense of the diverse labour market incorporations among different ethnic groups and the diverse social networks built by their communities. Not accounting for the broad historical-structural context experienced by each particular migrant group in the process of incorporation to the host society opens the doors to stereotyping. By erasing the broad historical and political-economic context that precedes the incorporation to the labour market, and placing the emphasis only on the latter, it is easy to simplistically conclude that the failure or success of an ethnic group depends on how hard they work, how disciplined and motivated they are or whether the community's social capital is positive or negative. This kind of reductionism leads to praising the privileged and blaming the victims. In order to avoid an economistic interpretation, the notion of mode of incorporation, which in the literature under discussion refers mainly to the labour market, will be conceptualised here more broadly to include global and national political, cultural and social dimensions the ensuing processes will be referred to as the socio-political mode of incorporation.

\section{Historical origins of Caribbean migration to the USA}

By the late nineteenth century, the USA had special economic and political interests in the region. The Caribbean was perceived by the US political elites as an important region for both commercial routes to South America and as a strategic 


\section{Puerto Ricans in the USA: a comparative approach.}

military location for the defence of the US mainland against an European invasion (Estades-Font 1988). These two considerations mobilised the political elites to establish an aggressive strategy of direct military interventions for the political-economic control of the region. Four of the five islands in the Greater Antilles were invaded between 1898 and 1916. Puerto Rico and Cuba were invaded in 1898, Haiti in 1915 and the Dominican Republic in 1916. These interventions served to render the islands peripheral yet again, but this time in a context of US, rather than European, domination over their political and economic processes (Grosfoguel 1997a). US capital investments increased dramatically in the region to control directly the sugar plantations and the sugar trade.

Official labour recruitment was established in the territories under US military control: Puerto Ricans after 1900 were recruited by US sugar corporations to work in Hawaii, the Dominican Republic and Cuba; Haitians were recruited to work at sugar estates in the Dominican Republic and Cuba after 1915; also under British rule as of the 1900s, Jamaicans were recruited by the thousands to work at US sugar estates in Cuba; and thousands of Barbadians were recruited to build the Panama canal under the US flag (Baez-Evertz 1986: 188-96; Castor 1971: 84; Foner 1983: 9; Perez de la Riva 1979: 34-39).

Of greater importance to our topic, the 1900-1920 period saw the start of both the initiation of mass labour migration from the Caribbean to the US mainland and the foundation of the first Caribbean communities in the US. This shift was part of a global transformation of migration processes. Rather than being a colonising migration from the expanding commercial centers of the world-system to the subordinated regions, instead it became a population movement from the periphery in response to the needs of the new industrial centres (Portes and Walton 1981).

During the First World War the flow of immigrants coming from Europe was affected, thus increasing the recruitment of Caribbean labour. Thousands of Jamaicans, Puerto Ricans, and Cubans were recruited for agrarian and menial jobs as part of the on-going war efforts. By 1920, there were around 35,000 Afro-Caribbean West Indians just in New York City (Light 1972).

For the next 25 years (1920-1945) the absolute numbers of Caribbean migrants declined compared to the large numbers of the first two decades of the century (Bryce-Laporte 1983). The labour unions' demand that immigration be restricted, the Great Depression and the Second World War affected the entrance of new Caribbean migrants. Thus, the 'internal minorities', especially black Southerners but also Puerto Ricans (after 1917 they were US citizens), became the main source of cheap labour for the Northeast industrial complex. New York City became one of the main destinations of these racialised/colonial migrants.

The 1924 Immigration Act that restricted European migration to the USA further accelerated the massive migration of these internal colonial subjects to New York. As the Euro-American workers became upwardly mobile with their increased skills and job opportunities in higher-wage industries, the low-wage manufacturing jobs in the garment and apparel industries became an undesirable economic sector identified with racialised minorities. During the 1920s and 1930s African-Americans became the main source of cheap labour in New York City's manufacturing sector and low-wage services. Puerto Ricans were the second largest group with approximately 30,000 newcomers in the 1920s. The racialisation of these colonial subjects was reflected in the low wages they received in the garment industry sweatshops relative to white workers of different ethnicities. As early as 1929 , Puerto Ricans and African-Americans earned $\$ 8-\$ 13$ per week while Jewish and Italian workers earned \$26-\$44 per week (Laurentz 1980: 90, 104).

During the Second World War the USA relied on Mexican migrants (through the Bracero Program) for cheap labour in Southwest agriculture and on women in Northern industries. Puerto Ricans were recruited through a Federal Program war effort to work in agriculture and industries in the Northeast during the Second World War (Maldonado 1979). It was after 1945, when the war was over and women were sent back to the 'kitchens', that Caribbean migration increased to the former pre-1920s levels. This was a period of increased segmentation in the labour market (Portes and Bach 1985). This refers to the emergence of a dual-labour market divided between an oligopolistic and a competitive sector. The former is characterised by stable labour relations in capital intensive industries through internal promotion and increases in wages as productivity increased. The latter were low-wage, menial jobs in labour-intensive industries. Caribbean migrants were massively recruited in the competitive sector. The great majority of the 1940s and 1950s Caribbean immigrants were Puerto Ricans recruited for low-wage jobs in the post-war expansion of the competitive capitalist manufacturing and service industries in New York City. 


\section{Puerto Ricans in the USA: a comparative approach.}

The Cuban revolution during the 1960s and the approval of the liberal 1965 Immigration Act brought about a major transformation in the ethnic composition of Caribbean immigration to the USA. Cuban political refugees took first place in terms of total numbers of Caribbean immigrants both for the 1960s and the 1970s. The most interesting development in this period, though, was the substitution of the African-Americans and Puerto Ricans for the 'new immigrants' as the major source of cheap labour in the secondary labour market of 'global cities' like New York, especially after the 1973 crisis (Sassen 1988). Labour migration from the Dominican Republic, Jamaica and other Caribbean islands (not including Puerto Rico and Cuba) increased to proportions never seen before. From comprising merely 7 per cent of the total Caribbean legal immigrants in the 1950s, they increased dramatically to 46 per cent in the 1960 s, 60 per cent in the 1970 s and 63 per cent in the 1980s. This increase of 'new immigrants' was also reflected in the significant decrease of Puerto Rican migrants from the peak of 450,413 (79 per cent of the total Caribbean legal migrants) in the 1950s, to only 57,217 (7 per cent) in the 1970s. This is significant because it reflects a major change in the source of cheap labour in the US economy, namely, from domestic minorities to the 'new immigrants'. This leads to the question of who migrates? From what sectors of the sending societies are these migrants?

The class composition of the post-1960s Caribbean migrants

Since these islands do not share a border with the receiving society, Caribbean countries in the majority of the cases send migrants who can afford to acquire a visa and/or to pay for the journey. Contrary to popular beliefs, there is a consensus in the literature that those who migrate are the most urban, educated, skilled workers, and with household incomes that are higher than those of the sectors at the bottom of the sending society (Bray 1984; DeWind and Kinley III 1988; Foner 1979, 1983; Grasmuck and Pessar 1992; Pedraza-Bailey 1985; Portes and Bach 1985; Stepick and Portes 1986).

There are three exceptions to these patterns: the Puerto Rican migration, the Haitian 'boat people', and the Cuban 'marielitos'. First, Puerto Ricans represent an anomaly because they are US citizens and live in a territory under US jurisdiction. Although the Puerto Rican pre-1950s migration was composed of urban skilled and educated workers because they were the only ones who could afford the transportation expenses (Vazquez-Calzada 1979), after 1950 air fares were significantly reduced between the island and the mainland (Bach 1985). The unrestricted border alongside the reduced air fare has signified that the bulk of the 587,535 Puerto Rican migrants during the 1950-1980 period came from the unskilled and low-income sectors, many of them from rural areas (Centro de Estudios Puertorriquenos 1979; Grosfoguel 1992; Levine 1987). During the 1980s, more than 200,000 Puerto Ricans migrated to the USA. This migration was more representative of all social classes on the island and the majority settled in new communities out of New York City.

The second exception is the recent wave of new Haitian immigrants that has landed illegally on the shores of South Florida after crossing 700 miles of open sea aboard small boats. Estimates are that between 50,000 and 70,000 Haitians arrived between 1977 and 1981. Managing to avoid border restrictions, the Haitian 'boat people' are definitely from lower status and more rural background than the Haitian legal immigrant cohort to the USA between 1962 and 1980 (Stepick and Portes 1986). The former settled in South Florida while the latter settled in New York City. Haitian 'boat people' come from low educational and occupational backgrounds. The results of a recent survey still reveals a population with above-average levels of education and income by Haitian standards (Stepick and Portes 1986). Even though the illegal sea journey migration is accessible to more Haitians than the legal air travel with a visa, only those with above average income can afford to pay the illegal fare.

Third, the migration of 125,000 Cubans in 1980, through the port of Mariel to South Florida, is another exception to the Caribbean upper and middle level labour immigration pattern. Most of these immigrants were unskilled labourers from the lower strata of the Cuban society (Pedraza-Bailey 1985, Portes and Bach 1985).

In sum, Caribbean migrants can be characterised as a labour migration composed mainly of the most urban, employed middle sector workers in the sending countries. Only colonial migrants such as Puerto Ricans and 'boat people' such as Haitians/Cubans in South Florida are an exception to this general trend. This raises the question of the nature of the modes of incorporation of Caribbean immigrants in the USA.

Modes of incorporation to the host society

Contrary to the human capital approach, which emphasises individual attributes, structuralist explanations emphasise the 


\section{Puerto Ricans in the USA: a comparative approach.}

macrostructures of the capitalist labour process. However, both approaches share an overemphasis upon societies' economic processes, overlooking the social and political relationships mediating the relations between an ethnic group and the labour market. This is where a non-reductive social relational approach emphasising the socio-political mode of incorporation can offer new insights that enrich the structuralist perspective. A basic assumption of this approach is that market relationships are embedded in social relations (Block 1990; Grannovetter 1985), that is, the market is not insulated from political relations, state policies and social relations. Rather than a rational subject consciously calculating the most profitable choices, there are individuals or groups embedded in social relations with other individuals or groups which condition their alternatives and choices within peculiar social contexts.

The implications of the socio-political mode of incorporation approach for our topic is the reconceptualisation of the economistic conception of the immigrants' modes of incorporation in that they are conceptualised as embedded in social, political, and cultural relations. In other words, a particular immigrant group's labour market incorporation is the outcome of the interaction between the class origin of the immigrant group and the multiple social determinations composed by the socio-political mode of incorporation within the host society. Whether the host government's policy is one of active support or opposition to the immigrant group, the public opinion is of acceptance or discrimination, the country of origin is perceived by the core state as a friend or an enemy, or the immigrant group has access to an ethnic community that provides capital and social networks of solidarity to the newly arrived or not, are all factors which make a significant difference in terms of the particular mode of incorporation into the labour market. The notion of 'socio-political modes of incorporation' is close to Portes and Rumbaut's (1990) notion of 'context of reception'. The main difference is that while the former emphasises the global political-economic relationship between the host and sending society, the latter emphasises the national setting of the host society. Contrary to Portes and Rumbaut (1990), it is the US government's geo-political policies toward the Caribbean which overall determine the public opinion and the ethnic community resources. The US government's policy toward Caribbean migrants has been dependent on political strategic considerations in the region (Grosfoguel 1997b). Global symbolic strategies aimed at gaining a capital of prestige vis-a-vis the Soviet Union during the Cold War play a crucial role in terms of understanding US policies toward the Cuban and Puerto Rican migration. For example, the Cubans in Miami were a geo-political showcase vis-a-vis the Cuban regime. To make them successful was an important ideological weapon during the Cold War years to influence ideologically those that stayed on the island (Grosfoguel 1994; 1997b). Thus, they received billions in government aid to open businesses and improve their educational levels (Cronin 1981; Dominguez 1992; Grosfoguel 1994; Pedraza-Bailey 1985; Dominguez 1992). On the other hand, Puerto Ricans on the island were a geo-political showcase of capitalism vis-a-vis the Soviet model represented by Cuba. Puerto Rico's model of development - better known as 'industrialisation by invitation' - was promoted around the world by the USA as a way of gaining a capital of prestige and honour, or symbolic capital (Bourdieu 1977), for the US model of development (Grosfoguel 1997b). Thus, the migration of the lower strata was stimulated and encouraged as a way of cleaning up the island of the unemployed and the shantytowns (Grosfoguel 1997b). This policy paved the way for the first mass airway migration in world history. Approximately 600,000 Puerto Ricans, mostly rural unskilled workers, migrated to the mainland in the 20-year period between 1950 and 1970. Since the Puerto Rican showcase was the island rather than the migrants, the USA channelled its resources to the island. Those who migrated ended up in the urban ghettos of the metropolis with one of the highest poverty rates in the USA.

Similarly, US policies toward Haitian refugees have been discriminatory for racial as well as geo-political reasons. In this case one consideration was the support to the Duvalier dictatorship as a containtment strategy against communism in the region (Grosfoguel 1997b). To support the refugees would have been an indirect critique to a friendly anti-communist dictatorship. Thus, in contrast to the Cuban refugees who until very recently were received with open arms, Haitians were detained in jails or simply deported back to Haiti. Such factors are crucial in terms of accounting for the success or failure in the incorporation to the labour market of different Caribbean groups in the USA.

Caribbeans offer an excellent example of the immigrants' multiple forms of incorporations into the receiving society's labour market depending on their class origins and diverse socio-political modes of incorporation. There is a diversity of modes of incorporations within the same ethnic groups. However, each ethnic group has a dominant trend. At one extreme, we have Cubans who migrated during the 1959-1979 period and, at the other extreme we have the Haitian 'boat people' during the 1980s, both of whom arrived in South Florida. The mode of incorporation for the Cuban refugees during the Cold War years was characterised by:

(1) an active government support with the creation of the Cuban Refugee Program to help them resettle succesfully into the host society (Pedraza-Bailey 1985); 


\section{Puerto Ricans in the USA: a comparative approach.}

(2) a positive public opinion; and

(3) an entrepreneurial community which offered jobs and opportunities to the newly arrived, insulating them from discrimination in the open market (Portes and Bach 1985).

In contrast to this migration, the Haitian 'boat people' in South Florida encountered opposition to entry from the host government, a discriminatory public opinion and no ethnic community to serve as a buffer against discrimination.

Between these two extremes there are a variety of other modes of incorporation. First, the 1980's 'Mariel' Cubans who experienced a discriminatory public reception had no active government support and but had an entrepreneurial ethnic community which incorporated them at least more succesfully than the Haitians in South Florida (Portes and Stepick 1985). The next two cases are the skilled/white-collar immigrants from Jamaica and Haiti in New York City who arrived between 1965 and 1980. New York's large black community and a multicultural environment served as a curtain for both ethnic groups to pass unnoticed. Thus, both have experienced passive acceptance from the government and a relatively positive public opinion concerning their particular ethnicity. In a post-civil rights era, the dominant Euro-American groups used the West Indian presence in the city to 'showcase' them vis-a-vis African-Americans. West Indians were portrayed as 'hard working people' vis-a-vis the 'lazy' domestic minorities such as African-Americans. In the Haitian case, there was no public hysteria against their settlement in New York before 1980 as there was in South Florida during the 1980s. Since both Haitians and Jamaicans are primarily of Afro-Caribbean descent and settled near African-Americans, they avoided the racism directed against the African-American community in New York City by emphasising ethnic over racial identity. However, one major difference between the African-Americans and the immigrants from Haiti and Jamaica is the higher educational levels of the latter (Grasmuck and Grosfoguel 1997). Meanwhile, the main diferences between Haitians and Jamaicans in the USA are: 1) the host society's stronger prejudices against Haitian culture; 2) the existence of a large white-collar community in the Jamaican case versus a more diversified working class community in the Haitian case; and 3 ) the Jamaican's first language is English, while for the Haitians it is Creole. Thus, despite the fact that both groups share high educational levels, the Jamaicans are economically more successful than the Haitians.

The Puerto Ricans have some of the worst socioeconomic conditions in the USA. The first large wave of Puerto Rican migrants were skilled/urban labourers between 1900 and 1945. During this period, Puerto Ricans were actively recruited during and after the First World War as cheap labour for the manufacturing industries in New York City. The second large wave of Puerto Rican migrants were mostly unskilled/rural labourers during the 1950s and

1960s. Most of them found support networks in the Puerto Rican working class communities in New York City. They encountered a passive acceptance by the US government, a negative acceptance in terms of public opinion and an inefficient/bureaucratised Migration Division Office, an office of Puerto Rico's Department of Labour organised to encourage mass labour migration. The Migration Division established offices in New York and Chicago to assist the migrants in finding jobs and to follow up any complaint concerning their civil rights (Lapp 1990). However, the Migration Division had little power and will to intervene on behalf of the workers. Despite this minimal institutional support, public opinion of the Puerto Rican migrants was overlaid with discrimination. For reasons that will be discussed below, public opinion of Puerto Rican migrants became extremely negative and the social conditions of the communities deteriorated. The new migrants suffered from overcrowded and dilapidated housing, lack of institutional support for education and poor medical services. In New York's racially and ethnically divided labour market Puerto Ricans occupied the economic niche of low-wage manufacturing jobs. By 1960, more than 50 per cent of Puerto Ricans in New York were incorporated as low-wage labour in this sector. During the 1960s, Puerto Ricans were actively organised in labour unions and through the civil rights struggles started claiming equal rights. Many labour rights that were violated in the past by employers through repressive mechanisms and misinformation were now claimed by Puerto Ricans as part of their citizenship rights. Puerto Ricans' successful struggles for labour rights made them 'too expensive' for the increasingly informalised manufacturing sector (Grasmuck and Grosfoguel 1997). Simultaneously, the de-industrialisation of the Northeast, the region where most of the Puerto Ricans settled, led to the loss of thousands of manufacturing jobs. Most of the manufacturing industries moved to peripheral regions around the world while those that stayed in locations like New York, Philadelphia, or Hartford informalised their activities. The manufacturing industry, in constant need of cheap labour, relied heavily on new Latino immigrants, legal or illegal, that had even fewer rights than internal colonial subjects such as the Puerto Ricans. The expulsion of Puerto Ricans from manufacturing jobs and an educational system that excluded Puerto Ricans from the best state-funded schools produced a redundant labour force that could not re-enter the formal labour market (Grasmuck and Grosfoguel 1997). This led to the formation of what some have called the Puerto Rican 'underclass', which I prefer to call 


\section{Puerto Ricans in the USA: a comparative approach.}

a racialised displaced population. Unable to find jobs, many Puerto Ricans developed popular strategies, legal or illegal, to survive the crisis. Currently, only 14 per cent of Puerto Ricans are in manufacturing and more than 50 per cent are either unemployed or out of the labour force (Grasmuck and Grosfoguel 1997). Around 40 per cent of the Puerto Rican labour force is currently concentrated as cheap labour in retail trade and in services such as health, administrative support and educational occupations (U.S. Department of Commerce 1993, Table 4).

In sum, the Puerto Ricans migrants' unskilled working class backgrounds combined with a negative socio-political mode of incorporation produced a massive incorporation into the secondary labour market and later, with de-industrialisation, a massive marginalisation from the labour market. Today they have one of the worst socioeconomic profiles of all ethnic groups in the USA. Puerto Ricans have one of the highest unemployment rates, lowest labour force participation rates and highest poverty rates among Caribbean groups in the USA.

\section{Puerto Ricans and the US national foundational myths}

What rights did the Puerto Rican migrants have when they arrived in the USA and how were they perceived by the metropolitan populations? This is related to the history and particularity of the type of colonialism practiced by the metropoles. The extension of citizenship to colonial Puerto Rico in 1917 by the USA to draft Puerto Rican males during the First World War institutionalised the formation of second class citizens. Puerto Ricans were supposed to have legal access to the different rights of citizenship, however, as a racialised colonial group within the USA, their access to those rights was limited.

Why do Puerto Ricans experience discrimination and marginalisation despite the fact that they share metropolitan citizenship? The concept of nation is crucial for the understanding of citizenship, identity and the socio-political modes of incorporation. In order to talk about the rights (civil, political, social) and the obligations that citizenship (T.H. Marshall 1964) implies, we need to understand the foundational myths, invented traditions (Hobsbawn 1990), imaginary communities (Anderson 1983) that states, dominant elites, dominant classes and/or dominant racial/ethnic groups construct to draw a boundary between those who belong to and those excluded from the representations of the nation. What are the founding myths that capture the construction of a given national identity? In the USA a central myth is the 'American dream'. The USA is supposed to be the land of opportunities for immigrants from all over the world; where the harder you work, the more successful you become. One implication of this myth is that if an 'ethnic' group fails, it is because they have not worked hard enough and that therefore there has to be something wrong with them.

The 1776 Bill of Rights was constructed on the basis of 'We the people' rather than 'We the citizens..... This implies that citizenship is perceived more in terms of group rights rather than individual rights, excluding those outside the imaginary community called the American people. This allowed for the recognition of ethnic rights for 'white' people. A country composed of multi-ethnic immigrants such as the USA did not base the reproduction of citizenship in terms of an ethnocultural differentialist Volk-centered approach such as Germany nor on a centralised political unity expressed in the assimilationist policies striving for cultural unity such as France. To be American became identified with 'whiteness' which was the unifying theme of all the multi-ethnic European immigrants. The myth of the 'melting pot' was strongly dominated by an Anglo-Saxon ethnicity and always refered to the 'melting together' of white people. Thus, race became a central category for people to be included in or excluded from the 'nation'. At the establishment of the US Constitution in the late eighteenth century, black people were excluded from the Bill of Rights. 'Ehtnic' was a term used to refer to Europeans, while people of colour were racialised and excluded from constitutional rights.

It is within the context of these foundational myths about the nation that we can discuss how citizenship defines who is included or excluded from the nation. In the USA, civil rights, in terms of rights to property, and political rights, in terms of rights to vote, have always been stronger than social rights. The myth of making it through hard work, the American dream, leaves a narrow space in the social imaginary for the notion of social rights. This is an important factor, although not the sole one, in understanding the underdeveloped welfare state in the USA. However, whatever the rights, they are perceived or imagined to be deserved by 'white' people, while racial/ethnic minorities are perceived as intruders or opportunists that want to take advantage of these rights. In the USA the social classification of peoples has been hegemonised by 'white' male elites throughout a long historical process of colonial/racial domination. The categories of modernity such as citizenship, democracy, and national identity have been historically constructed through two axial divisions: 1) between labour and capital, and 2) between Europeans and non-Europeans (Quijano 1991). 'White' male elites hegemonised these axial divisions. According to the concept of 'coloniality of power' developed by Anibal Quijano, 


\section{Puerto Ricans in the USA: a comparative approach.}

even after political independence, when the formal juridical/military control of the state passed from the imperial power to the newly independent state, 'white' elites continued to control the economic and political structures. This continuity of power from colonial to post-colonial times allowed the 'white' elites to classify populations and to exclude people of colour from the full exercise of citizenship in the imaginary community called the 'nation'. The civil, political, and social rights that citizenship provided to the members of the 'nation' were selectively expanded over time to 'white' working classes.

However, 'internal colonial' groups remained 'second class citizens', never having full access to the rights of citizens and the 'imagine community' called the nation. Being American was incompatible with being black, Puerto Rican, native-American, Asian, etc. Thus, the civil right struggles of these racialised subjects were built around the notion of equality, claiming equal rights as racialised ethnic minorities suffering discrimination within the USA. The subsequent development was the implementation of minority group rights based on affirmative action programmes.

In the USA the word ethnic has historically referred to cultural differences among 'white' European groups (e.g. Italian, Irish, German) while racial categories have been used to refer to people of colour (e.g. of black, Asian, Hispanic extraction), erasing ethnic differences within these racially classified groups. Categories such as Latino or Hispanic, although politically useful for certain struggles, mix together diverse ethnic groups with heterogeneous experiences that cannot be subsumed under a single label. However, since the 1960s 'ethnic' in the USA has become a code word for race. 'Ethnic' are those racialised groups excluded from the 'imagine community' while 'American' is the 'national identity' used to refer to 'white' people. This shift in the dominant discourses on race occurred as a response to the 1960s civil rights movement. Rather than characterising groups along racial lines, 'ethnic' and 'migrant' were coined as the new terms. This emerging dominant discourse was elaborated by Nathan Glazer and Daniel P. Moynihan in their now classic Beyond the Melting Pot: The Negroes, Puerto Ricans, Jews, Italians, and Irish of New York City (Cambridge: The M.I.T. Press, 1963). The experience of people of colour in the USA is equated to that of the 'white' migration from Europe at the beginning of the twentieth century. By transmuting racial discrimination into ethnic discrimination, Puerto Ricans and African-American can go through the same experiences of any other ethnic group and eventually be economically, socially, and politically incorporated as were the 'white' European migrants before. Consequently, poverty and marginalisation is due to a 'cultural problem' within the 'ethnic' community rather than a discrimination problem from the Euro-American dominant groups. This approach obliterates the history of racial/colonial oppression experienced by African-Americans and Puerto Ricans: African-Americans' long colonial history of slavery and political/racial barriers to upward mobility and Puerto Rico's colonial regime that expropriated the land and incorporated the people as cheap labour in sugar plantations first and in manufacturing later in Puerto Rico and the USA. Puerto Ricans and African-Americans are not simply migrants or ethnic groups, but rather colonial/racialised subjects in the USA. Both are formally citizens, but without exercising their rights fully due to the history of racial/colonial domination.

A 'cultural' form of 'racism' emerged in the USA during the 1960s civil rights struggles when it became 'politically incorrect' to continue articulating a racist discourse based on traditional biological reductionist discourses. 'Cultural racism' is the dominant discourse about race today (Balibar 1991; Gilroy 1987). 'Cultural racism' implies that the metropolitan 'culture' is different from the minorities 'culture' but understood in an absolutist, essentialist sense, that is, 'we are so different that we cannot get along together', or 'you belong to an inferior culture that does not understand the cultural rules of the American society'. Another articulation is: 'the problem with the poverty or unemployment of black people and Puerto Ricans is due to their habits, beliefs, that is, their culture', implying cultural inferiority and naturalising/fixing/essencialising culture. This is always related to a notion of 'biological racism' to the extent that 'culture' is naturalised in terms of some notion of inferior versus superior nature. 'Culture of poverty' arguments is a form of 'cultural racism'. The Puerto Ricans were among the first groups to be racialised along these lines (Lewis 1966).

Unable to place Puerto Ricans in a fixed racial category (neither white nor black) due to the mixed racial composition of the community, white Americans increasingly perceived them as a racialised Other. Puerto Ricans became a new racialised subject, different from white and black, sharing with the latter a subordinate position to the former. The film West Side Story probably marked a turning point where Puerto Ricans became a distinct racialised minority, no longer to be confused with Asians, black people or Chicanos, in the social imaginary of white America. This racialisation was the result of a long historical process of colonial/racial subordination on the island as well as on the mainland (Santiago 1994; Vazquez 1991). The racism experienced by Afro-Puerto Ricans in many instances can be stronger than that experienced by lighter-skinned Puerto Ricans. However, no matter how 'blond or blue-eyed' a person may be nor whether s/he can 'pass', the moment that person identifies her/himself as Puerto Rican, s/he enters the labyrinth of racial Otherness. Puerto Ricans of all colours have become a racialised group in the imaginary of white Americans, marked by racist stereotypes such as laziness, violence, stupidity and dirtiness. Although Puerto Ricans form a phenotypically variable group, they 


\section{Puerto Ricans in the USA: a comparative approach.}

have become a new race' in the USA. This highlights the social rather than biological character of racial classifications. The deprecative classification of Puerto Ricans as 'spics' in the symbolic field of New York designates the negative symbolic capital attached to `Puerto Rican’ identity.

\section{Puerto Rican identification strategies}

What strategies have racialised subjects pursued in the struggle against racism in the USA? An important strategy has been the construction of identities that subvert the exclusion from the dominant imaginary community called the nation. Different ethnic groups in the USA have used hyphenated identities in order to deconstruct the attempt by the dominant groups to exclude them from citizenship rights on the bases of race and/or ethnicity. Today we see the black community using the term African-American as a strategy of incorporation to the mainstream of American society. A similar strategy has been pursued by other groups such as Mexican-Americans, Cuban-Americans, Haitian-Americans,

Korean-Americans and even Dominican-Americans. The only racialised group that has resisted this hyphenated identity are the Puerto Ricans. It is very rare to find a Puerto Rican using this hyphenated form of identity. Even those born and raised in the USA keep using the non-hyphenated Puerto Rican identity. This is partly related to resistance against being fully assimilated to a society that marginalises and racialises Puerto Ricans. Discrimination reinforces a feeling of belonging to, and an idealisation of, the imagined place of origin. Moreover, this feeling is more pronounced with the constant circulation of Puerto Ricans given the open border between the island and the mainland. Many second, third and even fourth generation Puerto Ricans in the USA keep a feeling of belonging to the Puerto Rican imaginary community even if they have never visited the island. This sense of belonging is fed through family and social networks between the island and the metropolitan communities. The Puerto Rican identity persists despite the rejection and discrimination suffered when second and third generation Puerto Ricans visit the island. Similar to the term 'negropolitan' in the Martinican experience, second-generation Puerto Ricans who return are frequently stereotyped with names such as 'nuyorican.' The cultural hybridity of Puerto Ricans in the USA is not tolerated not only by nationalist intellectuals on the island but also by Puerto Rican middle classes. The 'nuyoricans' question some of the racist and elitist representations of Puerto Rican identity on the island. The cultural hybridity of the Puerto Ricans in the USA represents a form of identity which includes elements of African-American culture that threatens island elites' efforts to conceal their African heritage privileging the Spanish culture. Moreover, it shows how there are heterogeneous ways of being Puerto Rican, and that a Puerto Rican identity is not reducible to a question of a common language or any other shared feature. Puerto Rican as a form of identity means different things for Puerto Ricans born and raised either on the island or in the USA. Many middle class Spanish-speaking Puerto Ricans on the island are more assimilated to American 'white' middle-class cultural practices with their suburban houses, cable T.V., racist representations of Puerto Rican identity and mass consumption in fancy shopping centres than many non-Spanish-speaking Puerto Ricans in the USA living segregated in urban ghettos. Thus, there is an important difference in the content and claims of Puerto Rican identity on the island and on the mainland. To identify as Puerto Rican with no hyphenation implies a challenge to the racism of the US urban racial/ethnic hierarchies. However, there is a cost attached to this challenge in the USA that does not exist on the island, where Puerto Rican identity has become the colonial administration 'national identity' vindicated by all political forces (Grosfoguel et al. 1997).

Some people have used the metaphor of 'commuter nation' to refer to the Puerto Rican 'guagua aerea' (airbus) between the island and the mainland (Rodriguez-Vecchini 1994). Although the non-hyphenated Puerto Rican identity in the USA might seem close to a notion of a de-territorialised nation, it would be essentialist to think of Puerto Rican identity in the USA as a simple extension of the Puerto Rican national identity produced on the island. The implication of this would be a static, non-relational notion of identity, as if the migration experience did not transform the identity of the migrants into a new hybrid, syncretic form of identity both in the metropole as well as on the island. Puerto Rican migrants' emerging forms of identities do not precisely reproduce either the national identity of the country of origin nor the identities of the metropolitan society. They mix, redefine, resignify and reappropiate a multiciplicity of practices from different cultures, redeploying cultural practices of the country of origin in new and transformed ways.

The identification processes of Puerto Ricans transcends the concepts of nation and ethnicity. Puerto Ricans articulate their identity in the transnational space between the metropole and the island through ethnic and national claims simultaneously. When social and civil rights are at stake, Puerto Ricans make claims as an ethnic group within the metropolitan state, that is, as a minority that belongs to a broader unit. When cultural and political rights are at stake due to certain inconvenient metropolitan policies, Puerto Ricans mobilise a national discourse claiming autonomy. In this sense, notions of 'nation' or 'ethnicity' used separately come short when attempting to understand the identity processes 


\section{Puerto Ricans in the USA: a comparative approach.}

of Puerto Ricans. Puerto Rican identity has diverse meanings in different contexts. Thus, the notions of transnation (Appadurai 1996), transnationalism (Basch et al. 1994) or 'ethno-nation' (Grosfoguel et al. 1997) are better notions if we mean by that an emerging form of hybrid identity that transcends the categories of ethnicity and nation by assuming and surpassing both forms simultaneously. The transnational identities of Puerto Ricans are new forms of hybrid, post-national identities that capture and mobilise, according to the socio-political context, diverse forms of identities such as ethnic, national, or minority simultaneously. 'Ethno-nation' refers more to a process rather than to a concept or a fixed reality with emphasis on both sides of the hyphen depending on context (Grosfoguel et al. 1997). Each individual, even if of extreme nationalist persuasion, reproduces the ambiguities of transnationalism which emerge from the ambiguous status of colonial people like Puerto Ricans. Sharing citizenship and a non-independent status with the metropoles produces an ambiguous situation to the extent that on some issues people mobilise discourses on national identity while on others they articulate themselves as an ethnic group within the metropole. Puerto Ricans use their metropolitan citizenship to claim access to US government programmes, or deploy discourses on national identity to defend cultural rights or to avoid unwanted metropolitan laws both on the island and in the metropole. Identities need to be understood as constructions that emerge out of political strategies within specific power relationships. It is in a post-national sense that Puerto Rican identity formation is transnational.

\section{References}

Anderson, B. (1983) Imagined Comunities, London: Verso

Appadurai, A. (1996) Modernity at Large, Minnesota: University of Minnesota Press

Bach, R. (1985) 'Political frameworks for international migration' in S.S. Sanderson (Ed.), The Americas in the New International Division of Labor, New York: Holmes and Meier

Baez-Evertz, F. (1986) Braceros haitianos en Republica Dominicana, Santo Domingo: Instituto dominicano de Investigaciones Sociales

Balibar, E. (1991) 'Is there a neo-racism?' in E. Balibar and I. Wallerstein (Eds), Race, Nation, Class: Ambiguous Identities, London: Verso

Basch, L., N. Glick Schiller and C. Szanton-Blanc (1994) Nations Unbound: Transnational Projects, Postcolonial Predicaments and Deterritorializaed Nation-States, Amsterdam: Gordon and Breach Publishers

Block, F. (1990) Postindustrial Possibilities: A Critique of Economic Discourse, Berkeley: University of California Press

Bourdieu, P. (1977) Outline of a Theory of Practice, Cambridge: Cambridge University Press

Bray, D. (1984) 'Economic development: the middle class and international migration in the Dominican Republic', International Migration Review Vol. 18 No. 2:217-36

Bryce-Laporte, R.S. (1983) Caribbean Immigrations and their Implications for the United States, Washington, D.C.: The Wilson Center

Castor, S. (1971) La ocupacion norteamericana de Haiti y sus consecuencias 1915-1934, Mexico: Siglo XXI

Centro de Estudios Puertorriquenos (1979) Labor Migration Under Capitalism, New York: Monthly Review Press

Cronin, D.M. (1981) `Ethnicity, opportunity and occupational mobility in the United States', Ph.D. Dissertation, State University of New York, Stony Brook

DeWind, J. and D.H. Kinley III (1988) Aiding Migration: The Impact of International Development Assistance on Haiti, Boulder: Westview Press

Dominguez, J.I. (1992) 'Cooperating with the Enemy?: U.S. Immigration Policies toward Cuba', in C. Mitchell (Ed.), 


\section{Puerto Ricans in the USA: a comparative approach.}

Western Hemisphere Immigration and United States Foreign Policy, University Park, PA: The Pennsylvania State University Press

Estades Font, M.E. (1988) La presencia militar de Estados Unidos en Puerto Rico: 1989-1918, Puerto Rico: Ediciones Huracan

Estades Font, M.E. (1979) 'West Indians in New York City and London: a comparative analysis', International Migration Review Vol. 13, No. 2:284-97

Foner, N. (1983) 'Jamaican migrants: a comparative analysis of the New York and London experience', Occasional Papers No. 36. New York: New York University, Center for Latin American and Caribbean Studies

Gilroy, P. (1987) 'There Ain't No Black in the Union Jack': The Cultural Politics of Race and Nation, Chicago: Chicago University Press

Glazer, N. and D.P. Moynihan (1963) Beyond the Melting Pot, Cambridge: The M.I.T. Press

Gordon, M.M. (1964) Assimilation in American Life, New York: Oxford University Press

Granovetter, M. (1985) 'Economic action and social structure: the problem of embeddednes', American Journal of Sociology Vol. 91:481-510

Grasmuck, S. and P. Pessar (1992) Between Two Islands: Dominican International Migration, Berkeley: University of California Press

Grasmuck, S. and R. Grosfoguel (1997) 'Geopolitics, economic niches, and gendered social capital among recent Caribbean immigrants in New York City', Sociological Perspectives Vol. 40, No. 3: 339-63

Grosfoguel, R. (1992) 'Puerto Rico's exceptionalism: industrialization, migration and housing development, 1950-1970', Ph.D. Dissertation, Temple University

Grosfoguel, R. (1994) 'World cities in the Caribbean: the rise of Miami and San Juan', Review Vol. XVII, No. 3 (Summer): 351-81

Grosfoguel, R. (1997a) 'The divorce of nationalist discourses from the Puerto Rican People' in F. Negron-Muntaner and Ramon Grosfoguel (Eds), Puerto Rican Jam!: Rethinking Colonialist and Nationalist Discourses, Minnesota: University of Minnesota Press

Grosfoguel, R. (1997b) 'Migration and geopolitics in the Greater Antilles: from the Cold War to the post-Cold War', Review Vol. XX No. 1, Winter: 115-45

Grosfoguel, R., F. Negron-Muntaner and C. Georas (1997) 'Beyond nationalist and colonialist discourses: the Jaiba politics of the Puerto Rican ethno-nation' in F. Negron-Muntaner and R. Grosfoguel (Eds), Puerto Rican Jam!: Rethinking Colonialist and Nationalist Discourses, Minnesota: University of Minnesota Press

Hobsbawn, E.J. (1990) Nations and Nationalism since 1780, Cambridge: Cambridge University Press

Lapp, M. (1990) `Managing migration: the migration division of Puerto Rico and Puerto Ricans in New York City, 1948-1968', Ph.D. Dissertation: Johns Hopkins Universty

Laurentz, R. (1980) 'Racial/ethnic conflict in the New York City garment industry, 1933-1980', Ph.D. Dissertation, State University of New York at Binghamton

Levine, B.B. (1987) 'The Puerto Rican exodus: development of the Puerto Rican circuit' in B.B. Levine (Ed.) The Caribbean Exodus, New York: Praeger 


\section{Puerto Ricans in the USA: a comparative approach.}

Lewis, O. (1966) La Vida: A Puerto Rican Family in the Culture of Poverty - San Juan and New York, New York: Random House

Light, I. (1972) Ethnic Entrepreneurs in America: Business and Welfare among Chinese, Japanese, and Blacks, Berkeley: University of California Press

Maldonado, E. (1979) 'Contract labor and the origin of Puerto Rican communities in the United States', International Migration Review Vol. 13, Spring: 103-21

Marshall, T.H. (1964) Class, Citizenship and Social Development, Garden City, N.Y.: Doubleday

Omi, M. and H. Winant (1986) Racial Formation in the United States, New York: Routledge

Park, R.E. (1950) Race and Culture, Glencoe, Illinois: The Free Press

Pedraza-Bailey, S. (1985) Political and Economic Migrants in America: Cubans and Mexicans, Austin: University of Texas Press

Perez de la Riva, J. (1979) 'Cuba y la Migracion Antillana, 1930-1931', Anuario Estadistico de Estudios Cubanos 2: La Republica Neo-Colonial, Havana: Editorial de Ciencias Sociales

Petras, E. (1981) 'The global labor market in the modern world-economy' in M. Kritz, C.B. Keely and S.M. Tomasi (Eds), Global Trends in Migration: Theory and Research on International Population Movements, New York: Center for Migration Studies

Portes, A. and R. Bach (1985) Latin Journey: Cuban and Mexican Immigrants in the United States, Berkeley: California University Press

Portes, A. and J. Borocz (1989) 'Contemporary immigration: theoretical perspectives on its determinants and modes of incorporation', International Migration Review Vol. 23, No. 3 (Fall): 606-30

Portes, A. and A. Stepick (1985) 'Unwelcome immigrants: the labor market experiences of 1980 (Mariel) Cuban and Haitians Refugees in South Florida', American Sociological Review Vol. 50 (August): 493-514

Portes, A. and R.G. Rumbaut (1990) Immigrant America: A Portrait, Berkeley: University of California Press

Portes, A. and J. Walton (1981) Labor, Class, and the International System, Orlando, FI.: Academic Press

Quijano, A. (1991) `Colonialidad y Modernidad/Racionalidad’, Peru Indigena Vol. 29, 11-21

Rodriguez-Vecchini, H. (1994) 'Foreword: back and forth', in C.A. Torre, H. Rodriguez-Vecchini and W. Burgos (Eds), The Commuter Nation, Rio Piedras: Editorial de la Universidad de Puerto Rico

Santiago, K. (1994) "Subject People" and Colonial Discourses, Albany: State University of New York Press

Sassen, S. (1988) The Mobility of Labor and Capital: A Study in International Investment and Labor Flow, London: Cambridge University Press

Stepick, A. and A. Portes (1986) 'Flight into despair: A profile of recent Haitian refugees in South Florida', International Migration Review Vol. 20 (Summer): 329-50

U.S. Department of Commerce (1993) Persons of Hispanic Origin in the United States, Washington, D.C.: Bureau of the Census

Vazquez-Calzada, J.L. (1979) 'Demographic aspects of migration' in Centro de Estudios Puertorriquenos (Eds), Labor 


\section{Puerto Ricans in the USA: a comparative approach.}

Migration Under Capitalism, New York: Monthly Review Press

Vazquez, B. (1991) 'Puerto Ricans and the media: a personal statement', Centro Vol. 3, No. 1:5-15

Ramon Grosfoguel is Assistant Professor in the Sociology Department at Boston College. He is a research associate of the Fernand Braudel Center (Binghamton University) and the Maison des Sciences de l'Homme in Paris. He is currently working on a book entitled 'Colonial Caribbean Migrations to France, The Netherlands, Great Britain and the United States (1945-1995)'.

Ramon Grosfoguel

Sociology Department

McGuinn Hall 426

Boston College

140 Commonwealth Ave.

Chestnut Hill, MA

USA 02167-3807

E-mail: grosfog@ix.netcom.com 